\title{
EVALUATING UTILIZITION OF DISCARDED DATES AS A SOURCE OF ENERGY FEEDSTUFF IN THE DIETS OF GROWING NEW.ZEALAND WHITE GROWING RABBITS
}

\author{
Walaa A. Salama; M.A. El-Shora; Marwa A. Suliman and A.I. Abd-El- Lateif \\ Animal Production Research Institute, Agricultural Research Center, El-Dokki, Giza, Egypt. \\ Corresponding author: Walaa A. Salama.E-mail: Address: walaa.attia2@gmail.com
}

(Received 1/10/2015, Accepted 29/11/2015)

\section{SUMMARY}

$\mathrm{T}$ This study was conducted to investigate the influence of using discarded date as a source of energy to replace of 25, 50 and $75 \%$ instead of barely grains in growing New Zealand rabbit diets on growing rabbit performance. A total number of 48 unsexed, weaned New Zealand White rabbits of 6 weeks old were randomly divided into four experimental groups (12 for each). Four pelleted experimental diets were formulated to be approximately isocaloric, isonitrogenous and isofibrous. The trail lasted about 8 weeks and experimental group animals were allotted to receive four experimental diets. Insignificant $(\mathrm{P} \geq 0.05)$ differences were observed in feed consumption among the different experimental groups. Using of 25 and $50 \%$ discarded date in growing rabbit diets increased significantly live body and daily weight gain. Feed conversion ratio was significantly improved with feeding 25 and $50 \%$ discarded date compared to control diet. Replacing $25 \%$ of the barely by discarded date significantly increased the values of DM, CP, CF digestibilities and percentages of TDN, DE and NB compared to the other groups. Also using 50\% discarded date as replacer to barely significantly increased the values of DM and CF digestibility than the other groups. Discarded dates at levels $25 \%$ in the diets, led to significant differences in empty carcass and dressing percentage $\%$ compared to the control groups. Using $75 \%$ discarded date as replacer to barely significant increase the values of catalase than the other groups. Data showed significantly decreased in the value of lipid peroxidase for rabbits fed on diets containing of discarded dates at levels 50 and $75 \%$ compared to the control groups. Analysis of variance revealed that using 25 or $50 \%$ discarded dates as instead to barely significantly increased the value of total volatile fatty acid and ammonia concentration compared to the control group. Discarded dates at levels 25 and $50 \%$ led to significant differences in triiodothyronine hormone $\left(\mathrm{T}_{3}\right)$ compared to control group. Using 25,50 and $75 \%$ discarded dates as a source of energy in growing rabbit diets decrease feed cost and improve economic efficiency.

In general, the results indicated that using discarded dates in rabbit diets with rate of $75 \%$ of barely grains reduced fed costs without adverse effects on performance of rabbits.

Keywords: discarded date, Rabbits, Growth, Digestibility, blood constituents and cecum characteristics.

\section{INTRODUCTION}

The price of the main ingredients in poultry and rabbits diets is constantly growing. So, new unconventional local sources of low price ingredients need to be identified and validated. The feed cost of animal nutrition represents more than $70 \%$ of the total production cost. It is now urgent to look for alternative feedstuffs to compensate the high cost of the conventional feedstuffs. Rabbits are herbivores and consume high fiber diets. Useless the digestive strategy of rabbits for the utilization of fibrous diets was described by (Cheeke, 1982). Rabbits can separate fiber and non-fiber components and retain nonfiber components for fermentation in the cecum. Egypt is the second important country in date world production which produce 1.373 .570 ton (FAO, 2011). Palm date is produced largely in the hot and arid regions of the Middle East and North Africa and remains an extremely important subsistence product in many of the desert areas. Discarded dates are characterized by having high total digestible nutrients and being palatable for livestock (Al-Dobaib et al., 2009). Animal performance is closely related to there generation of metabolism and functioning of the endocrine system. A close relationship between thyrotropin-releasing hormone (THR), thyroid stimulating hormone (TSH), triiodothyronine $\left(\mathrm{T}_{3}\right)$, Thyroxin $\left(\mathrm{T}_{4}\right)$ and growth hormone $(\mathrm{GH})$ had been found and this axis plays an important role in growth (Cogburn et al., 1995). Many animal-herds owners in different countries that producing dates are using discarded dates as a supplement to their animals feed. It is the high time to use local unconventional 


\section{Salama et al.}

sources of feed to fill the gap between demand and supply of the limited feed resources and to substitute the conventional high-priced imported sources (Almitairy et al., 2011). Date waste contains carbohydrates and minerals and is a good source of energy, Palm date byproducts such as discarded dates and date pits could be used in formulation of diets for animals as energy sources not only for ruminants but also for rabbits (Al-Yousef et al., 1994), replacing a part of the energy concentrates in the diet. The value of energy in the diet and the source of energy affect animals feed conversion efficiency (Nunes, 1994). Date fruit can provide $2.67 \mathrm{Mcal} / \mathrm{kg}$ of digestible energy. Dates contain approximately $78.5 \%$ dry matter, $2.2 \%$ crude protein, $0.5 \%$ fat, $2.3 \%$ crude fiber, $72.9 \%$ carbohydrate and $1.9 \%$ ash, so it can supply $87 \%$ of the digestible energy provided by the same unit of traditional grain feed (Alkhateeb and Ali-Dinar, 2001). The flesh of date contains $0.2-0.5 \%$ oil, where the seeds contain $7.7-9.7 \%$ oil. Unsaturated fatty acids include palmatic, oleic, linoleic and linolenic acids were found. The oleic acid content of the seeds varies from 41.1 to $58.8 \%$ which suggest that the seeds and date could be used as a source of oleic acid (AlShahib and Marshall, 2003).Cull dates could efficiently be used as useful ingredients in the ration of small ruminants taking into account the right proportion of dates added. Therefore, using cull dates in feeding small ruminants could be economically sound in hot climate countries (Alhomidy et al., 2011). Palm date and its fibers have several nutritional values such as antioxidant activity (Al-Farsi et al., 2007and Amoros et al., 2009). The antioxidant activity could be due to its lignin content in dates, since lignin has been shown to possess antioxidant and antimicrobial activities (Brunow, 2006). Kamel et al., (1981)reported that whole ground dates replacing maize at respectively 5, 10 and 30\% of a diet for broilers supported growth as efficiently as the control, but $47.7 \%$ as a total replacement of the maize resulted in growth depression and reduced feed utilization. Also, Kah (2008) reported that growth performance of chicks fed $15 \%$ Palm Kernel Cake (PKC) replacement of maize was better than chicks fed 20\% Palm Kernel Cake (PKC) replacement of maize. AL-Dobaib et al., (2007) found that growth performances of rabbits fed diets containing 0,15 or $30 \%$ of discards dates did not attain significant differences in growth performance.

Hence, the objectives of the present study were to investigate the effects of dietary inclusion of discarded dates on performance rabbits and feed cost.

\section{MATERIALS AND METHODS}

This study was carried out at Poultry Research Station, Animal Production Research Institute, Agricultural Research Center, Ministry of Agriculture, Egypt in Kafr EL-Sheik Governorate, Forty eight weaned New Zealand White (NZW) rabbits, six weeks old with an average live body weight ranging from 705.00 to $747.50 \mathrm{~g}$ were allotted randomly to receive four treatment with four groups (twelve rabbits /treatment in 3 replicates). Four pelleted experimental diets were formulated using linear programming, to be approximately isonitrogenous to cover the requirement of growing rabbits according to NRC (1977) and Cheeke (1987). All animals were receiving control diet for one week before the start of the experimental period. Feed and water were offered ad libitum. Four experimental diets were formulated; including the control diet without discarded dates while the other three diets were of discarded dates at $7.80,15.60$ or $23.40 \%$ in the diet $(25,50$ or $75 \%$ of barely) as shown in Table 1. Discarded dates were obtained from Luxor Governorate, Egypt. Discarded dates were ground by hammer mill and kept for chemical analysis before mixing to the diets. Chemical analyses of discarded dates and barely grains presented in Table 2 . The digestible energy (DE $\mathrm{kcal} / \mathrm{kg}$ ) of discarded dates and barely grains were calculated according to the equation of Cheek (1987). Feed intake and weight gain were recorded weekly, while feed conversion was calculated as gram of feed per gram of gain. The experimental period lasted for 8 weeks. At the end of the experimental period, a digestibility trial was conducted to determine the digestibility coefficient of the nutrients according to (Fekete, 1985).

Digestibility trial was carried out using four male rabbits from each experimental group at the last week of the experiment (14 weeks of age). The rabbits were housed in metabolic cages where feces and urine were collected separately for 6 days as a collection period during which the feces were collected daily sprayed with $2 \%$ boric acid solution for trapping any ammonia released from feces. At the end of this period, the feces were dried at $60^{\circ} \mathrm{C}$ for 48 hours (till constant weight), finely ground and thoroughly mixed to ensure sample uniformity and then stored until being analyses. Urine was collected into buckets containing $100 \mathrm{ml}$ of $\mathrm{H}_{2} \mathrm{SO}_{4}(10 \%)$ to prevent $\mathrm{N}$ losses. The volume of urine at each sampling was recorded and sub - sample (10\%) was taken for each rabbit and stored at $-20^{\circ} \mathrm{C}$ for analysis of total $\mathrm{N}$. Proximate analysis of the diets and feces were carried out according to the methods of AOAC (2000). At the end of the experimental period (14 weeks of age), four rabbits were randomly taken from each group and fasted for 12 hours before slaughtering to determined carcass characteristics according to Steven et al. (1981). As follows: 
Dressing $\%=$ dressing weight $\times 100$ /pre slaughter body weight.

Where dressed weight $=$ weight of empty carcass with head.

Also 4 animals from each group were slaughtered to study cecum characteristics as total volatile fatty acids were determined according to Eadie et al. (1967), ammonia was determined by applying Conway method (1958) and determined blood parameters as total protein (Gornal et al. 1949), albumin (Doumas and Waston, 1971), transaminase (AST, aspartate aminotransferase and ALT , alanine aminotransferase, Reitman and Frankel (1975). Catalase (Aebi 1984), Glucose (Trinder, 1969), Lipid Peroxidase (Malondialdehyde) (Satoh, 1978). The concentrations of Thyroid hormones (triiodothyronine $\left(\mathrm{T}_{3}, \mathrm{ng} / \mathrm{ml}\right)$ and thyroxin $\left(\mathrm{T}_{4}, \mathrm{ng} / \mathrm{ml}\right)$ in plasma were determined according to Barker and Silverton (1982) by using commercial kits supplied by Monobind Inc.

The economic efficiency (EEF) was calculated according to the following equation: $\mathrm{EEF}=$ Net revenue / total costs Where the total cost calculated by Egyptian pound (L.E.) in the local market at the time of experiment. All data were subjected to analysis of variance using the general linear models (GLM) procedure of SAS (2004). By the following model: $Y i j=\mu+\mathrm{Ti}+$ eij, Where: $\mu=$ overall mean of Yij, $\mathrm{T}=$ effect of treatment, $\mathrm{i}=(1,2 \ldots$, etc $)$ and eij= experimental error.

The Significant differences among treatment means were separated at alpha level $(\mathrm{P} \leq 0.05)$ by Duncan's multiple range test (1955).

Table (1). Ingredients of experimental diets (on DM basis).

\begin{tabular}{|c|c|c|c|c|}
\hline \multirow{2}{*}{ Ingredients } & \multirow{2}{*}{ Control } & \multicolumn{3}{|c|}{ Discarded dates } \\
\hline & & $25 \%$ & $50 \%$ & $75 \%$ \\
\hline Soybean meal $(44 \% \mathrm{CP})$ & 14.25 & 15.95 & 17.45 & 19.25 \\
\hline Barely grains & 29.00 & 21.75 & 14.50 & 7.25 \\
\hline Discarded dates & ------- & 7.25 & 14.50 & 21.75 \\
\hline Wheat bran & 15.00 & 15.00 & 15.00 & 15.00 \\
\hline Clover hay & 35.20 & 33.50 & 32.00 & 30.20 \\
\hline Lime stone & 0.70 & 0.70 & 0.70 & 0.70 \\
\hline Calcium Carbonate $\left(\mathrm{CaCO}_{3}\right)$ & 2.00 & 2.00 & 2.00 & 2.00 \\
\hline Sodium Chloride $(\mathrm{NaCl})$ & 0.30 & 0.30 & 0.30 & 0.30 \\
\hline Vit.\& min. Mix ${ }^{1} *$ & 0.30 & 0.30 & 0.30 & 0.30 \\
\hline DL-Methionine & 0.20 & 0.20 & 0.20 & 0.20 \\
\hline Anticoccidia(Diclazuril) & 0.05 & 0.05 & 0.05 & 0.05 \\
\hline Molasses & 3.00 & 3.00 & 3.00 & 3.00 \\
\hline Total & 100 & 100 & 100 & 100 \\
\hline \multicolumn{5}{|l|}{ Chemical analysis\% } \\
\hline DM\% & 88.80 & 88.83 & 89.50 & 89.02 \\
\hline \multicolumn{5}{|c|}{ Chemical analysis\% (on DM basis) } \\
\hline OM\% & 89.76 & 88.94 & 88.80 & 88.50 \\
\hline $\mathrm{CP} \%$ & 16.20 & 16.34 & 16.38 & 16.40 \\
\hline $\mathrm{CF} \%$ & 14.73 & 14.65 & 14.60 & 14.50 \\
\hline $\mathrm{EE} \%$ & 2.15 & 2.32 & 2.47 & 2.64 \\
\hline NFE $\%$ & 56.68 & 55.63 & 55.35 & 54.96 \\
\hline Ash\% & 10.24 & 11.06 & 11.20 & 11.50 \\
\hline$* * \operatorname{DE}(\mathrm{kcal} / \mathrm{kg})$ & 2464.66 & 2467.24 & 2468.85 & 2472.08 \\
\hline \multicolumn{5}{|l|}{ Calculated analysis\% } \\
\hline Calcium & 1.29 & 1.28 & 1.27 & 1.26 \\
\hline Total phosphorus & 0.79 & 0.77 & 0.76 & 0.74 \\
\hline Methonine & 0.43 & 0.49 & 0.46 & 0.47 \\
\hline Lysine & 0.82 & 0.88 & 0.94 & 1.01 \\
\hline
\end{tabular}




\section{RESULTS AND DISCUSSION}

\section{Chemical composition:}

The chemical analyses of discarded dates and barely grains as shown in Table (2). Where it contained comparable CP (5.12 vs. 12.40), CF (9.18 vs. 5.72), EE (4.34 vs. 2.60), NFE (67.73 vs. 76.74), ASH (13.54 vs. 2.54) and DE (2643.89 vs.2755.50) as compared with barely grain. In this respect, AL-Dobaib et al. (2007) found that discarded dates contained CP (3.8\%), CF (2.8\%), EE (3.4\%) and ASH (10.4\%). And Abdel-Rahman et al. (2012) found that cull dates contain DM (87.15\%), CP (4.89\%), CF (3.60\%), EE (3.34\%) and ASH (10.23\%) Calcium (0.17) and phosphorus (0.03\%) .

Table (2). Chemical composition of discarded dates and barely grains (on DM basis).

\begin{tabular}{lcccccccc}
\hline & \multicolumn{7}{c}{ Chemical analysis\% (on DM basis) } \\
\cline { 2 - 8 } Item & DM\% & OM\% & CP\% & CF\% & EE\% & NFE\% & ASH\% & $*$ DE (Kcal/kg) \\
\hline $\begin{array}{l}\text { Discarded } \\
\text { dates }\end{array}$ & 85.26 & 86.46 & 5.12 & 9.18 & 4.43 & 67.73 & 13.54 & 2643.89 \\
$\begin{array}{l}\text { Barely } \\
\text { grains }\end{array}$ & 88.20 & 97.46 & 12.40 & 5.72 & 2.60 & 76.74 & 2.54 & 2755.50 \\
\hline
\end{tabular}

$* D E(k c a l / g)=4.36-0.0491 * N D F$, Where $N D F \%=28.924+0.657 * C F \%$ according to Cheeke $(1987)$

\section{Growth performance traits:}

As shown in Table (3), feeding growing rabbits on diets containing 25 and $50 \%$ discarded dates were increased significantly $(\mathrm{P}<0.05)$ final, total weight gain and daily body weight gain compared with those of control group. However, feeding growing rabbits on diets containing $75 \%$ discards dates were insignificantly increased $(\mathrm{P}<0.05)$ the average final weight and average daily weight compared with those of the control group. In this respect, AL-Dobaib et al. (2007) found that growth performances of rabbits fed diets containing 0,15 or $30 \%$ of discards dates instead of corn, barley and molasses did not attain significant differences in growth performance. In contrary, Soliman et al. (2009) and Ibrahim et al. (2010) found that diets contain date stone meal supplemented with enzymes improved growth performance of growing rabbits. Moreover, El-Manylawi and El-Banna (2013) indicate that date stone meal can be incorporated in rabbit diets up to $20 \%$ without any adverse effect on rabbit performance and up to $10 \%$ with adding Allzym.

Table (3). Effect of different levels of discarded dates on growth performance of growing rabbits.

\begin{tabular}{lccccc}
\hline \multirow{2}{*}{ Items } & \multirow{2}{*}{ Control } & \multicolumn{3}{c}{ Discarded dates } & SEM \\
\cline { 3 - 5 } & & $25 \%$ & $50 \%$ & $75 \%$ & \\
Experimental period (day) & 56 & 56 & 56 & 56 & 12.01 \\
Average initial body weight $(\mathrm{gm})$ & 747.50 & 705.00 & 727.50 & 720.00 & 37.57 \\
Average final body weight $(\mathrm{gm})$ & $1898.33^{\mathrm{b}}$ & $2105.00^{\mathrm{a}}$ & $2096.67^{\mathrm{a}}$ & $1918.33^{\mathrm{b}}$ & 3.89 \\
Average total weight gain $(\mathrm{gm})$ & $1150.83^{\mathrm{b}}$ & $1400.00^{\mathrm{a}}$ & $1369.17^{\mathrm{a}}$ & $1198.33^{\mathrm{b}}$ & 39.89 \\
Average daily body weight gain, (gm) & $20.55^{\mathrm{b}}$ & $25.00^{\mathrm{a}}$ & $24.45^{\mathrm{a}}$ & $21.39^{\mathrm{b}}$ & 0.94 \\
Average daily feed intake (gm) & 87.66 & 97.00 & 93.00 & 90.00 & 2.90 \\
& & & & \\
Average feed conversion ratio (gm) & $4.26^{\mathrm{a}}$ & $3.88^{\mathrm{b}}$ & $3.80^{\mathrm{b}}$ & $4.20^{\mathrm{a}}$ & 0.065 \\
feed/g gain) & & & & \\
\hline a,b,-- Means in the same row with different superscripts are significantly different $(P<0.05)$. &
\end{tabular}

Also, Almitairy et al. (2011) stated that the highest averages of daily gain and final weight were attained by $30 \%$ discarded dates for lambs which is significantly $(\mathrm{p}<0.05)$ higher than that of the control group followed by $15 \%$ discarded dates that is not differ significantly $(p>0.05)$ for both other groups. These results were in disagreement with that of Zadeh et al. (2015) who stated that increasing levels of discarded dates in diets increased body weight change of sheep. Body weight change highest was shown for sheep fed $30 \%$ discarded dates and lowest for sheep fed the control diet. Feed intake recorded highest value was occurred with rabbits fed on $25 \%$ discarded dates diet followed by rabbits fed a diet containing 50 and $75 \%$. While, the lowest value was occurred with rabbits fed on control diet. Generally, most tested 
diets didn't affect feed intake significantly in comparison with control. Feed intake increased with discarded dates may be due to the positive palatability effect of dates. However, feed intake decrease with increasing levels of dates may due to increase of neutral detergent fiber (NDF) and acid detergent fiber (ADF) by increased dates in diets. This interpretation is in accordance with Khattab (2013) who stated that increased neutral detergent fiber (NDF) and acid detergent fiber in sheep diets with increasing levels of dates led to decrease intake of OM and NFE in sheep. The best feed conversion ratio was obtained with 25 and 50\% discarded dates diets, while the worst one was obtained with control diet. In this respect, Almitairy et al. (2011) showed that daily feed intake was significantly $(\mathrm{p}<0.05)$ higher in $30 \%$ discarded dates for lambs than control group. Feed conversion ratio did not differ significantly ( $>>0.05)$ between the experimental groups. The positive effects of diets containing dates on the weight gain and fattening of animals may be due the presence of growth promoting compounds in dates (Ismail, 2000) and better efficiency utilization for energy and protein releasing to good synchronization between energy release (Volatile fatty acid) and protein degradation (ammonia) than more microbial protein yield (Al-Jassim et al. 1996).

\section{Nutrients digestibility, nutritive values and nitrogen balance:}

The results in Table (4) indicated that feeding growing rabbits on diets containing $25 \%$ discarded dates appeared to significantly $(\mathrm{P}<0.05)$ increase the digestibility coefficients and nutritive values of $\mathrm{DM}$, $\mathrm{CP}, \mathrm{CF}, \mathrm{TDN}, \mathrm{DE}$ and nitrogen balance $(\mathrm{NB}) \%$ compared with the control group. While, the group fed diets containing 25 and 50\% discarded dates did not affect digestibility coefficients significantly of OM, EE, NFE and DCP\% compared with the control group except digestibility coefficients of DM and CF\% significantly increased when growing rabbits were fed diets containing 50\% discarded date compared with the control group. There were insignificantly increased in the nutritive values of TDN, DE and NB \% when rabbits fed on diets containing of $75 \%$ discarded dates compared to control group. In this respect, El- Manylawi and El-Banna (2013) showed that adding Allzyme ${ }^{\circledR}$ SSF to the rabbits diets containing 10 or $20 \%$ date stone meal resulted in numerical increases in the digestibility of most nutrients compared to the other tested diets included the control. In accordance Alhomidy et al. (2011) found that digestibility of EE, DM and CP\% were significantly $(\mathrm{P}<0.05)$ higher in the sheep diets containing 30\% discarded dates than those containing 15\% discarded date as control ration, while $\mathrm{CF}, \mathrm{NDF}$ and $\mathrm{ADF}$ digestibility with 15 and $30 \%$ discarded date showed higher significant compared to the control diet. Also, El-Shora et al. (2014) found that the digestibility coefficients of all nutrients, nutritive values and the intake of DM, TDN and DCP were significantly $(\mathrm{P}<0.05)$ higher in cows diet containing 66\% discarded dates replacement of yellow corn grains. Than those containing $33 \%$ discarded dates while control almost had the lowest values. These results were in disagreement with Abdel-Rahman et al. (2012) who found that the TDN value of $100 \%$ cull dates replacement of yellow corn grains in the goat diets was insignificantly higher than that of other levels of replacement. Moreover, Zadeh et al. (2015). stated that urea nitrogen reduced by addition of levels discarded dates.

Table (4). Effect of different levels of discarded dates on nutrients digestibility, nutritive values and nitrogen balance of growing rabbits.

\begin{tabular}{lccccc}
\hline \multirow{2}{*}{ Items } & \multirow{2}{*}{ Control } & \multicolumn{3}{c}{ discarded dates } & SEM \\
\cline { 3 - 5 } & & $25 \%$ & $50 \%$ & $75 \%$ & SE \\
\hline DM \% & $63.00^{\mathrm{b}}$ & $68.36^{\mathrm{a}}$ & $68.23^{\mathrm{a}}$ & $64.72^{\mathrm{ab}}$ & 0.84 \\
OM \% & 67.76 & 70.74 & 70.13 & 68.89 & 0.85 \\
CP \% & $70.30^{\mathrm{b}}$ & $76.75^{\mathrm{a}}$ & $73.81^{\mathrm{ab}}$ & $71.30^{\mathrm{ab}}$ & 1.07 \\
CF \% & $31.12^{\mathrm{b}}$ & $42.60^{\mathrm{a}}$ & $39.57^{\mathrm{a}}$ & $36.32^{\mathrm{ab}}$ & 1.60 \\
EE \% & 80.13 & 83.68 & 82.17 & 83.78 & 1.70 \\
NFE\% & 71.33 & 76.90 & 74.06 & 72.31 & 1.70 \\
DCP \% & 11.38 & 12.54 & 12.09 & 11.69 & 0.63 \\
TDN\% & $54.88^{\mathrm{b}}$ & $65.18^{\mathrm{a}}$ & $58.65^{\mathrm{ab}}$ & $56.65^{\mathrm{b}}$ & 1.55 \\
DE kcal/kg* & $2431.1^{\mathrm{b}}$ & $2887.4^{\mathrm{a}}$ & $2598.1^{\mathrm{ab}}$ & $2509.5^{\mathrm{b}}$ & 69.56 \\
$\mathrm{NB} \%$ & $64.39^{\mathrm{b}}$ & $70.66^{\mathrm{a}}$ & $66.93^{\mathrm{ab}}$ & $66.23^{\mathrm{ab}}$ & 1.11 \\
\hline
\end{tabular}

$a, b,---$ Means in the same row with different superscripts are significantly different $(P<0.05)$.

$* D E=T D N X 44.3$ according to (Schneider and flatt, 1975). 


\section{Carcass characteristics:}

Carcass characteristics at 14 weeks of age of rabbits are presented in Table (5). The obtained results showed that replacing discarded dates at levels $25 \%$ in the diets, led to significant differences in empty carcass and dressing percentage $\%$ compared to the control group. While, replacing discarded dates at levels 50 or $75 \%$ in the diets did not effect in empty carcass and dressing percentage \%c compared to the control groups. These results were in disagreement with AL-Dobaib et al. (2007) who found that replacing 15 or $30 \%$ of discarded dates in rabbit diet didn't significantly affect dressing percentage. At the same time El-Manylawi and El-Banna (2013) showed that replacing date stone meal at levels 10 or $20 \%$ without or with Allzyme ${ }^{\circledR}$ SSF in the diets, led to insignificantly decreased in dressing percentage.

Table (5). Effect of different levels discarded dates on carcass characteristics of growing rabbits.

\begin{tabular}{lccccc}
\hline \multirow{2}{*}{ Items } & \multirow{2}{*}{ Control } & \multicolumn{3}{c}{ discarded dates } & SEM \\
\cline { 3 - 5 } & & $25 \%$ & $50 \%$ & $75 \%$ & SEM \\
\hline Live body weight, (Pre-slaughter)(g) & $1898.33^{\mathrm{b}}$ & $2105.00^{\mathrm{a}}$ & $2096.67^{\mathrm{a}}$ & $1918.33^{\mathrm{b}}$ & 37.57 \\
Empty carcass (g) & $816.33^{\mathrm{b}}$ & $1058^{\mathrm{a}}$ & $1011.33^{\mathrm{a}}$ & $903.67^{\mathrm{ab}}$ & 36.03 \\
Empty carcass\% & $43.00^{\mathrm{b}}$ & $50.26^{\mathrm{a}}$ & $48.24^{\mathrm{ab}}$ & $47.10^{\mathrm{ab}}$ & 0.90 \\
Head (g) & 124.00 & 131.01 & 129.66 & 126.33 & 1.62 \\
Liver (\%) & 2.12 & 2.40 & 2.36 & 2.21 & 0.05 \\
Kidney(\%) & 0.596 & 0.628 & 0.613 & 0.590 & 0.01 \\
Heart (\%) & 0.333 & 0.387 & 0.377 & 0.360 & 0.01 \\
Giblets(\% & 3.04 & 3.41 & 3.35 & 3.16 & 0.05 \\
Dressing (\%) & $49.53^{\mathrm{b}}$ & $56.48^{\mathrm{a}}$ & $54.41^{\mathrm{ab}}$ & $53.69^{\mathrm{ab}}$ & 1.15 \\
\hline
\end{tabular}

$a, b,---$ Means in the same row with different superscripts are significantly different $(P<0.05)$.

\section{Blood constituents:}

The plasma concentration values of glucose, total protein, albumin, aspartate and aminotransferase (AST) alanine aminotransferase (ALT), lipid Peroxidase (Malondialdehyde) (MDA), catalase are shown in Table (6). The obtained values of blood parameters were within the normal range. It could be noticed insignificantly differences in concentration of plasma glucose, albumin, total protein, ALT and AST of plasma for rabbits fed different tested treatments compared to control group. However, catalase was significantly increased with rabbits fed on diets containing discarded dates at level $75 \%$ compared to those fed on control diets. On the other hand, significantly decreased of lipid peroxides with rabbits fed on diets containing discarded dates at levels 50 and $75 \%$ were found. The obtained results were in agreement with those of AL-Dobaib et al. (2007) who found that total proteins, albumin, globulin, total lipids, were not differ of rabbits fed diets containing 15 and $30 \%$ of discarded dates while, there were significant decreased in cholesterol level for rabbits fed diet containing 30\% discarded dates. In contrary, Abdel-Fattah et al. (2012) found that partial substitution of ground yellow corn in concentrate feed mixture with ground date palm at $50 \%$ weight by weight slightly increased $(\mathrm{P}<0.01)$ blood total protein than control group of growing Barki lambs. Increasing of catalase and decreasing of lipid peroxidase may be due to the dates containing antioxidant substance this interpretation is in accordance with Amoros et al. (2009) who reported that palm date and its fibers have several nutritional values such as antioxidant activity. The antioxidant activity could be due to its lignin content in dates, since lignin has been shown to possess antioxidant and antimicrobial activities (Brunow, 2006).

Table (6). Effect of different levels of discarded dates on blood constituents of growing rabbits.

\begin{tabular}{lccccc}
\hline \multirow{2}{*}{ Items } & \multirow{2}{*}{ Control } & \multicolumn{3}{c}{ Discarded dates } & SEM \\
\cline { 3 - 5 } & & $25 \%$ & $50 \%$ & $75 \%$ & 1.06 \\
Glucose, mmol/l & 78.19 & 75.41 & 73.73 & 79.19 & 0.14 \\
Total protein, g/dl & 5.31 & 5.29 & 4.85 & 5.72 & 0.11 \\
Albumin, g/dl & 3.17 & 3.17 & 3.12 & 3.31 & 1.59 \\
AST(U/L) & 62.61 & 62.62 & 54.24 & 58.21 & 1.92 \\
ALT(U/L) & 60.71 & 59.28 & 57.80 & 62.91 & 0.43 \\
Lipid Peroxidase n, mol/ml & $11.72^{\mathrm{a}}$ & $9.89^{\mathrm{ab}}$ & $8.63^{\mathrm{b}}$ & $8.81^{\mathrm{b}}$ & 18.00 \\
(Malondialdehyde) (MDA) & $559.50^{\mathrm{b}}$ & $575.23^{\mathrm{b}}$ & $624.60^{\mathrm{ab}}$ & $684.90^{\mathrm{a}}$ & 18.00 \\
Catalase (U /l) & &
\end{tabular}

$a, b---$ Means in the same row with different superscripts are significantly different $(P<0.05)$. 


\section{Thyroid gland activity:}

Data presented in Table (7) showed that triiodothyronine hormone $\left(\mathrm{T}_{3}\right)$ was significantly $(\mathrm{p}<0.05)$ increased with rabbits fed diets containing discarded dates at level 25 and $50 \%$ compared to those fed control diets. However, there were insignificantly increased of thyroxin hormone $\left(\mathrm{T}_{4}\right)$ with rabbits fed diets containing discarded dates compared to control group. In this respect, Hashem (2014) stated that rams fed 50\% ground discarded dates in concentrate feed mixture has significant effect $(\mathrm{P}<0.05)$ on $\mathrm{T}_{3}$ and $\mathrm{T}_{4}$ hormones and increased body weight gain compared with control rams. And Abdel-Fattah et al. (2012) on Barki lambs fed ground date palm at Siwa Oasis and found that, there was a positive correlation between thyroid hormones $\left(\mathrm{T}_{3}\right.$ and $\left.\mathrm{T}_{4}\right)$ and body weight gain $(\mathrm{P}<0.01)$. Similar results reported by Mousa and AlSaiady (2002) who found that there was a positive correlation between thyroid hormones levels in serum and body weight during the growing period of Somali camels fed different levels of commercial feeds.

Table (7). Effect of different levels discarded dates on thyroid hormones of growing rabbits.

\begin{tabular}{lccccc}
\hline \multirow{2}{*}{ Items } & \multirow{2}{*}{ Control } & \multicolumn{3}{c}{ Discarded dates } & SEM \\
\cline { 3 - 5 } & & $25 \%$ & $50 \%$ & $75 \%$ & $0.59^{\mathrm{b}}$ \\
\hline$* \mathrm{~T}_{3}(\mathrm{ng} / \mathrm{ml})$ & $0.55^{\mathrm{b}}$ & $0.82^{\mathrm{a}}$ & $0.78^{\mathrm{a}}$ & 0.037 \\
$* * \mathrm{~T}_{4}(\mathrm{ng} / \mathrm{ml})$ & 6.24 & 7.34 & 6.85 & 6.68 & 0.20 \\
\hline
\end{tabular}

$a, b---$ Means in the same row with different superscripts are significantly different $(P<0.05)$.

$* T_{3}$ : Triiodothyronine hormone. $\quad * * T_{4}$ : thyroxin hormone.

\section{Cecum characteristics:}

Fermentation pattern in rabbit cecum resembles that in the rumen; however it shows lower fibrolytic microbial activity and relatively higher amylolytic and proteolytic microbial activity (Gidenne, 1997). The results of total volatile fatty acids value and ammonia concentration of caecal contents as shown in Table (8). Analysis of variance revealed that when growing rabbits fed diets containing 25 or $50 \%$ discarded dates significantly increased the value of total volatile fatty acids and ammonia concentration compared to the control group. While, when growing rabbits fed diets containing $75 \%$ discarded dates insignificantly increased of total volatile fatty acids and ammonia concentration compared to the control group. In this respect, Abdel-Rahman et al. (2012) stated that ruminal total volatile fatty acids values were significantly higher for goats fed $100 \%$ cull dates as replacement of yellow corn than control group and ammonia-nitrogen of $75 \%$ cull dates was higher than values of other groups. AL-Dobaib et al. (2007) found that caecal $\mathrm{pH}$ had no significant differences for rabbits fed on diets containing 15 and $30 \%$ discarded dates. While, caecal bacterial count was significantly decreased in rabbits fed on diet $15 \%$ discarded dates, while bacterial count increased in rabbits fed on diet $30 \%$ discarded dates. Moreover, ElShora et al. (2014) found that the highest TVFA's concentration in rumen liquor was recorded with in group fed $66 \%$ discarded dates after feeding, while the lowest concentration was found in control after feeding. Ammonia-nitrogen concentration in $66 \%$ discarded dates was higher before and after feeding than the other treatments.

Table (8). Effect of different levels discarded dates on cecum characteristics of growing rabbits.

\begin{tabular}{lccccc}
\hline \multirow{2}{*}{ Items } & \multirow{2}{*}{ Control } & \multicolumn{3}{c}{ discarded dates } & \\
\cline { 3 - 5 } & & $25 \%$ & $50 \%$ & $75 \%$ & SEM \\
\hline *TVFA $(\mathrm{mg} / 100 \mathrm{ml})$ & $3.48^{\mathrm{b}}$ & $4.79^{\mathrm{a}}$ & $5.09^{\mathrm{a}}$ & $3.69^{\mathrm{b}}$ & 0.22 \\
Ammonia(mg/100ml) & $8.26^{\mathrm{b}}$ & $9.50^{\mathrm{a}}$ & $9.63^{\mathrm{a}}$ & $8.39^{\mathrm{b}}$ & 0.24 \\
\hline
\end{tabular}

$a, b---$ Means in the same row with different superscripts are significantly different $(P<0.05)$.

*TVFA : Total Volatile Fatty Acid.

\section{Economic efficiency:}

Data presented in Table (9) showed that, the lowest total feed cost / rabbit (12.97 LE) was observed with rabbits fed the diets contained $75 \%$ discarded dates followed by that fed $50 \%$ discarded dates (14.01). Results also, indicated that groups fed the diets contained discarded dates at level $50 \%$ were achieved the highest economic efficiency followed by that fed $75 \%$ discarded dates (3.10 and 2.879) respectively, and relative economic efficiency (130.80 and 121.47) followed by a decreasing order by groups fed $25 \%$ discarded dates diet. And the least value was shown with group fed control diet. 
Generally, it can be noticed that rabbit fed on the diets contained discarded dates at levels 25,50 and $75 \%$ had higher economic return than control diets. These results were in agreement with Almitairy et al. (2011) who found that inclusion of $30 \%$ discarded dates as an alternative feed in lamb diets can reduce production costs. And also, Khattab (2013) found that replacement of corn grain with $100 \%$ dates can reduce the cost of concentrate mixture components of sheep diet.

From these results, it could be noticed that using discarded dates as a source of energy instead of a part of barely grains in growing rabbit ration tended to highest digestibility coefficient for all nutrients, feeding value and blood constituents of rabbits fed diets containing discarded dates may be due to dates contain vitamins and minerals (Khan et al., 2008). And dates contain high levels of selenium, copper, potassium, and magnesium, moderate concentrations of manganese, iron, phosphorus, and calcium and small quantities of boron (Barreveld, 1993) that improved health and improved growth of rabbits. and feed intake of dates helps to inhibit growth of the pathological organisms and thus, help to stimulate the growth of non pathogenic bacteria in the intestine, dates contain those insoluble and soluble fibers, as well as many beneficial amino acids which can stimulate the digestion of food and make it more efficient, meaning that more nutrients will be absorbed by the digestive tract and enter body for proper usage.

Moreover, using 25\% discarded dates appeared the highest economic efficiency and get the highest net revenue.

Table (9). Effect of different levels of discarded dates on economic efficiency of growing rabbits.

\begin{tabular}{lcccc}
\hline \multirow{2}{*}{ Items } & \multirow{2}{*}{ Control } & \multicolumn{3}{c}{ Discarded dates } \\
\cline { 3 - 5 } & & $25 \%$ & $50 \%$ & $75 \%$ \\
\hline Total average weight & 1150.83 & 1400.00 & 1369.17 & 1198.33 \\
price of 1kg body weight & 42 & 42 & 42 & 42 \\
Selling price/rabbit (LE) (A) & 48.33 & 58.80 & 57.50 & 50.32 \\
Total feed intake & 4.908 & 5.432 & 5.208 & 5.040 \\
Price/kg feed(LE) & 2.914 & 2.800 & 2.692 & 2.574 \\
Total feed cost/rabbit (LE) (B) & 14.30 & 15.20 & 14.01 & 12.97 \\
Net revenue(LE) $^{1}$ & 34.03 & 43.60 & 43.49 & 37.35 \\
Economic efficiency $^{2}$ & 2.37 & 2.86 & 3.10 & 2.879 \\
Relative Econ. Eff. $^{3}$ & 100 & 120.67 & 130.80 & 121.47 \\
\hline
\end{tabular}

(1) Net revenue $=A-B$.

(2) Economic efficiency $=(A-B / B)$.

(3) Relative Economic Efficiency= Economic efficiency of treatments other than the control/ Economic efficiency of the control group.

\section{CONCLUSION}

Conclusively, according to the circumstances of this experiment, discarded dates can be incorporated in rabbit diets $75 \%$ of barely grains without adverse effect on rabbit performance.

\section{REFERENCES}

Abdel-Fattah, M.S.; Abdel-Hamid Afaf, A.; Ellamie Ashgan, M.; M.M. El-Sherief and M.S. Zedan (2012). Growth Rate, Some plasma biochemical and amino acid concentration of Barki lambs fed ground date palm at Siwa Oasis, Egypt. American-Eurasian J. Agric.\& Environ. Sci., 12(9): 11661175.

Abdel-Rahman, H.H.; A.A. Abedo; Y.A.A. El Nomeary; M.M. Shukry; M.I. Mohamed and M.S. Zaki (2012). Response of re-placement of yellow corn with cull dates as a source of energy on productive performance of goat kids. Life Sci. J., 9(4): 2250-2255.

Aebi, H. (1984). Catalase in Vitro. Method Enzyme, 105: 121-126.

Al-Dobaib, S.N.; M.H. Khalil; M. Hashad and A.M. Al-Saef (2007). Growth, Carcass and ceacal traits in V- Line and crossbred rabbits fed diets containing discarded dates. World Rabbit Sci., 15: 81- 90. 
Al-Dobaib, S.N.; M.A. Mehaia and M.H. Khalil (2009). Effect of feeding discarded dates on milk yield and composition of Aradi goats. Small Ruminant Research, 81: 167-170.

Al-Farsi, M.; C. Alasalvar; M.Al-Abid; K. Al-Shoaily; M. Al-Amry and F. Al-Rawahy (2007).Compositional and functional characteristics of dates, syrups, and their by-products. Food Chem., 104: 943-947.

Alhomidy, S.N.; S. Basmaeil; A.N. Al-Owaimer; A.M. El-Waziry and M. Kooharaie (2011). Effect of digestion in sheep. Australian. Journal of Basic and Applied Science, 5(3): 636-640.

Al-Jassim, R.A.M.; S.A. Hassan and A.N. Al-Ani (1996). Metabolizable energy requirements for maintenance and growth of Awassi lambs. Small Ruminant Res., 20: 239-245.

Alkhateeb, A.A. and H.M. Ali-Dinar (2001).Date palm (phoenix dactyliferaL.) production and research in Kingdom of Saudi Arabia. The date palm International Symposium, Windhoek, Nambia.

Almitairy, M.H.; A.N. Alowaimer; A.M. El-Waziry and G.M. Suliman (2011). Effects of feeding discarded dates on growth performance and meat quality traits of Najdi lambs. Journal of Animal and Veterinary Advances, 10 (17): 2221-2224.

Al-Shahib, W. and R.J. Marshall (2003). The fruit of the date palm: its possible use the best food for the future?. International J. Food Sciences and Nutrition, (54): 247-259.

Al-Yousef, Y.M.; F.N. Al-Mulhim; G.A. El-Hag and G.A. Al-Gasim (1994). Apparent digestibility of discarded dates and date pits together with other agricultural by-products. Annals Agric.Sci., Ain shams Univ., 39(2): 655-662.

Amoros, A.; M.T. Pretel; M. S. Almansa; M. A. Botella; P.J. Zapata and M. Serrano (2009). Antioxidant and nutritional properties of date fruit from Elche grove as affected by maturation and phenotypic variability of date palm. Food Sci. Technol. Int., 15: 65-72.

A.O.A.C. (2000).Official methods of analysis. $17^{\text {th }}$ ed., published by the A.O.A.C., Washington, D.C., USA.

Barker, F.S. and R.E. Silverton, (1982). Introduction to Medical Laboratory Technology. 5th Ed. Publ. Butterworth S.C London, pp: 481-494.

Barreveld, W.H. (1993). Date palm products. Food and Agriculture Organization Agricultural Services Bulletin No. 101.

Brunow, G. (2006). In Biorefineries-Industrial Processes and Products; Kamm, B., Gruber, P.R., Kamm, M., Ed.; WILEY-VCH Verlag GmbH \& Co. KGaA: Weinheim, Gernany, 2 (4): 151-163.

Cheeke, P.R. (1982). High roughage diets utilization by rabbits. Feed International. 3, 46-51.

Cheeke, P.R. (1987). Rabbit Feeding and Nutrition. Academic Press, Orlando, Florida USA. 376p.

Cogburn, L.A.; N.C. Mao; S. Agrawal and J. Burnside (1995). Interaction between somatotropic and thyrotropic axes in regulation of growth and development of broiler chickens. Arch. Geflugel. Sonderh., 1: 18-21.

Conway, E.J. (1958).Micro Diffusion Analysis and Volumetric Error. $4^{\text {th }}$ ed. The McMillan Co., New York, USA, 687p.

Doumas, B.T. and W. Waston (1971). Albumin standards and measurement of plasma albumin with bromocresol green. Clin. Chem. Acta., 31: 87.

Duncan, D.B. (1955). Multiple Range and Multiple F-Test. Biometrics, 11: 1-42.

Eadie, J.M.; P.N. Hobson and S.O. Mann (1967). A note on some comparisons between the rumen content of barley fed steers and that of young calves also fed on high concentrate rations. J. Animal Production, 9:247-250.

El-Manylawi, M.A. and H.M. El-Banna (2013). Effect of feeding date stone meal supplemented with allzyme on performance of growing New Zealand rabbits. Egyptian J. Anim. Prod., 50(2): 103-109.

El-Shora, M.A.; M.H. Abo El-Fadel; T.A. Deraz and Y.M. El-Diahy (2014). Effect of using discarded dates on productive and reproductive performance of lactating cows. J. Animal and Poultry Prod., Mansoura Univ., 5(12): 775-789.

FAO (2011). Food and Agriculture Organization of the United Nations.

Fekete, S. (1985). Rabbit feeds and feeding with special regard to tropical condition. J. of Applied Rabbit Research, 8: 167-173.

Gidenne, T. (1997).Caeco-colic digestion in the growing rabbit :impact of nutritional factors and related disturbances. Livestock Production Sci., 51: 73-88. 


\section{Salama et al.}

Gornal A.G.; C.J. Bardawill and M.M. Divid (1949). Determination of plasma protein by means of the biurent reaction. J. Biol.Chem., 177: 751.

Hashem, A.L.S. (2014). Semen Physical Traits and Thyroid Activity of Barki Rams as Affected by Season and Feeding Non-Edible Date Palm at Siwa Oasis, Egypt. World Applied Sciences Journal, 30(5): 556-566.

Ibrahim, M.R.; H.M. El-Banna and M.A. El-Manylawi (2010). Evaluating utilization of ground date stone meal with or without kemzyme in the diets of growing New Zealand rabbits. IV International Date Palm Conference, 15-17 March, 2010, Abu Dubi, UAE. Acta Hort. (ISHS) 882:691-697.

Ismail, S. (2000). Non-conventional feed in animal nutrition and poultry (In Arabic) International Investments and culture- Egypt.

Kah, F.K. (2008). Formulation of chicks feed based on palm kernel cake (PKC). Award of the B.sci. Thesis, Fac. Ch. \& Nature Resources Engineering, University Malaysia Pahang, Malaysia, Abstract.

Kamel, B.S.; M.F. Diab; M.A. Ilian and A.J. Salman (1981). Nutritional value of whole dates and date pits in broiler rations. Poultry Science, 60(5): 1055-1011.

Khan, M.; A. Sarwar; M. Wahab and R. Haleem (2008). Physio-chemical characterization of date varieties using multivariate analysis. Journal of Food Agriculture 88: 1051-1059.

Khattab, I.M.; A. M. Abdel-Wahed and K. Z. Kewan (2013). Effect of replacing corn grain with dates in sheep diets on intake, digestibility, purine derivatives execretion, microbial nitrogen and rumen fermentation. Egyptian J. Nutrition and Feeds, 16 (2): 243-252

Mousa, I.A. and M.Y. Al-Saiady (2002). Thyroid hormones levels in growing male camels fed different levels of commercial feeds. J. King. Saud. Univ., Agric. Sci., 14(2): 71-76.

NRC (1977). National Research Council. Nutrient requirements of rabbits. Nat. Acad. Sci., Washington, DC.

Nunes, C.S. (1994). Microbial probiotics and their utilization in husbandry. Revista Portuguesa de Ciencias Veterinarias, 89:166-174.

Reitman, S. and Frankel, S. (1957). Determination of GOT and GPT Amr. J. Clin. Path., 28:56-63.

SAS (2004). User's guide. Statistic. SAS Inst. Cary, N.C. Releigh.

Satoh, K. (1978). Serum lipid peroxide in cerebro vascular disorders determined by a new colorimetric method. Clin. Chim. Acta., 15(1): 37-43.

Schneider, B.H. And W.P. Flatt (1975). The Evaluation of feed through digestibility experiments. University of Georgia Press Athens, Georgia, USA.423p.

Soliman, A.Z.M.; R.E. Khidr; M.A.F. EL-Manylawi and S.E.M. El-Sheikh (2009).Chemical and biological evaluation of date stone meal as an untraditional feedstuff in growing rabbit diets. The $5^{\text {th }}$ International Poultry Conference 10-13 March, Taba, Egypt. pp852-863.

Steven, Lukefapor, W.D.; W.D. Hohenboken; P.R. Cheeke; N.M. Patton and W.H. Kennick (1981).Carcass and meat characteristics of Flemish giant and New Zealand white purebred and terminal cross rabbits. Journal of Applied Rabbit Research, 4 (3): 66-72.

Trinder, P. (1969). Determination of blood glucose using an oxidase-peroxidase system with a noncarcinogenic chromogen. J .Clin Pathol., 22(2): 158-161.

Zadeh, J.B.; M.K. Nasrollah and A. Sajjad (2015). The Effects of different levels discarded dates on synthesis of microbial Protein in kermani sheep. International Journal of Life Sciences, 9(5): 45-49. 


\title{
تقيم إستخدام البلح الفرز كمصدر للطاقة فى علائق اللأرانب النيوزيلاندى الأبيض النامية.
}

ولاء عطيه سلامه، محمد احمد الثورى، مروه عبد المنعم سليمان و عطية إبراهيم عبد اللطيف

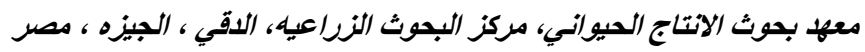

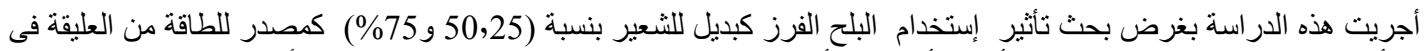

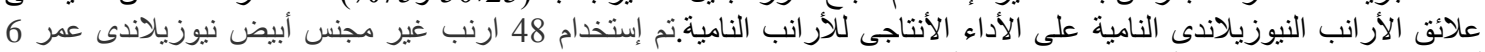

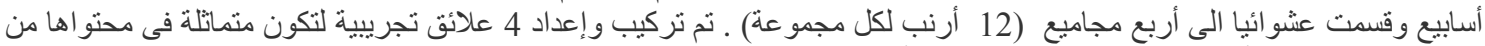
الطاقة و البروتين والألياف. إستمرت التجربة لمدة 8 أسابيع وغذيت مجمو عات الحيو انات التجربية على 4 علائق مختبرة وكانت النتائج

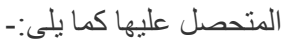

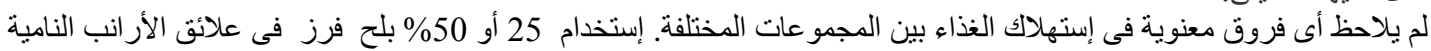

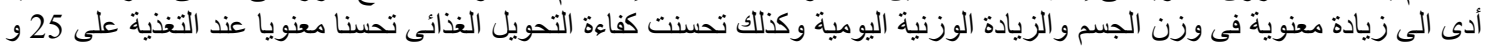

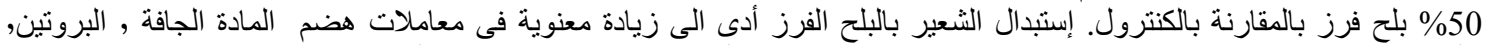

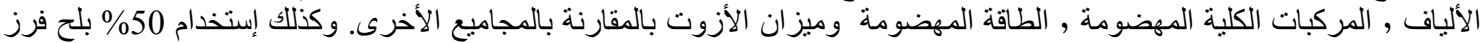

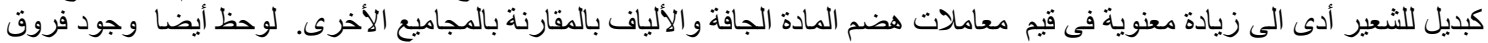

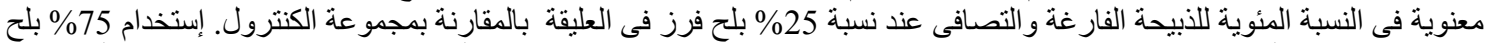

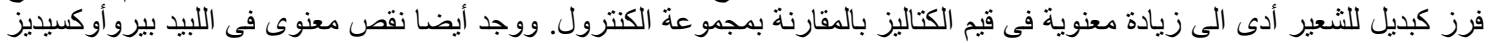

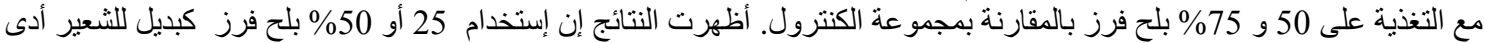

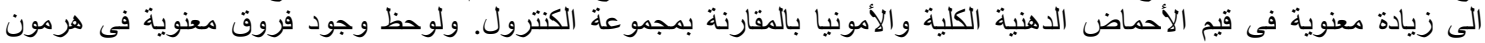

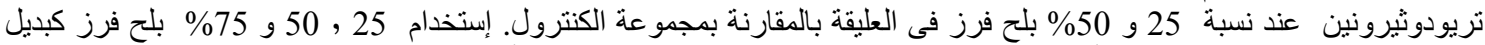

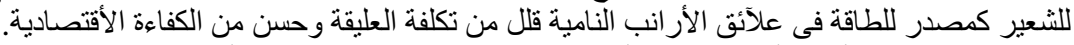

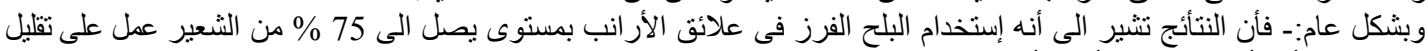
تكلفة العليقة بدون أى ثأثئر سيئ على أداء الأرانب النامية.
\end{abstract}

